F. Reprod. Fert. (1972) 30, 1-6

\title{
PATTERNS OF CHANGE IN THE REPRODUCTIVE ORGANS OF THE MALE POCKET GOPHER, GEOMYS PINETIS
}

\author{
KATHERINE CARTER EWEL* \\ Department of Zoology, University of Florida, Gainesville, Florida \\ (Received 6th April 1971, accepted 14th December 1971)
}

\begin{abstract}
Summary. The level of reproduction in the males of a population of the south-eastern pocket gopher, Geomys pinetis, has been found to vary with environmental changes. A principal components analysis of data obtained in this study suggests that changes in the reproductive condition of an individual male are related more to changes in the accessory sex glands than to fluctuations in spermatogenesis. Although Leydig cells gradually decrease in size after puberty, the cells still increase in diameter at times of increased reproductive activity, suggesting increased hormonal production. This cyclic change is correlated with increases in the height of the secretory epithelium in the accessory sex glands and in the epididymis.
\end{abstract}

\section{INTRODUCTION}

The south-eastern pocket gopher, Geomys pinetis Raf., does not appear to have a regular yearly breeding cycle. Wing (1960) has suggested that breeding continues throughout the year but not at the same rate; further evidence $(K$. C. Ewel, unpublished) indicates that the level of reproductive activity in a population may depend on environmental factors that increase or decrease the likelihood of intraspecific contact. The purpose of this study was to examine the relationships between the male reproductive organs in an animal whose breeding cycle does not vary in a regular manner but rather in response to relatively unpredictable environmental factors.

\section{MATERIALS AND METHODS}

Sixty-two adult male pocket gophers were trapped near Gainesville in monthly increments between March 1967 and July 1968. Certain standard measurements were taken: the lengths of the body, tail, hind foot and ear, and the body weight. Testis length and width, colour and vascularity were also recorded. Mature males were distinguished from immature males by a testis volume larger than $1000 \mathrm{~mm}^{3}$. This value was selected by comparing the logarithm of the testis volume with the logarithm of the body weight for all male pocket gophers, after the method described by Spencer (1968).

Sections were made of the right testis, cauda epididymidis and the entire

* Present address: Florida State Museum, University of Florida, Gainesville, Florida 32601, U.S.A. 
proximal set of accessory sex glands (prostates and seminal vesicles) of each male. These organs were preserved in Bouin's fixative, embedded in paraffin wax, sectioned at $10 \mu \mathrm{m}$, and stained with Heidenhain's iron-haematoxylin.

\section{Examination of the testis}

The volume of each testis was estimated by using the equation for a perfect ellipsoid. An average value for testis tubule diameter was also calculated for each individual from ten randomly selected round tubules.

Twenty tubules, randomly selected from the round tubules in several sections, were examined to determine the spermatogenic condition of each male, using the following scale adapted from Roosen-Runge \& Giesel (1950) with some modifications proposed by Johnson \& Buss (1967).

Stage 0 . No spermatocytes, tubules totally inactive

1. Primary spermatocytes present

2. Secondary spermatocytes present, some spermatids

3. Many spermatids beginning formation

4. Spermatids undergoing elongation but not yet in bundles

5. Spermatids in bundles moving toward tubule periphery

6. Spermatozoa moving from periphery to lumen; 'wheel-spoke' stage

7. $5 \%$ of tubules containing spermatozoa in lumen

8. $10 \%$ of tubules containing spermatozoa in lumen

Stages 9 to 15 increase accordingly in increments of $5 \%$, reaching $45 \%$ in Stage 15.

An 'active' testis might have a certain proportion of tubules at a stage earlier than Stage 6, since each section of an actively producing tubule could revert to any stage from 5 to 2 after losing its spermatozoa. An 'inactive' testis, i.e. one lacking any tubules actively producing spermatozoa, would have sections of tubules at Stages 0 to 3 , and even at Stage 5 .

In addition, those Leydig cells with visible nuclear and cell membranes were measured, and both the cell diameter and the nuclear diameter of round cells at $\times 1000$ were recorded. An estimation of the total number of Leydig cells in the testis was obtained by the method described by Groome (1940). The average Leydig cell diameter in each animal was then used to calculate the total volume of Leydig cell tissue in the testis; this value was divided by the testis volume for a measure of the percentage of the total volume.

\section{Examination of the epididymis and accessory sex glands}

The tubule diameter, cell height and nuclear diameter were each averaged over ten tubules in the cauda epididymidis.

The seminal vesicle in the young animal and in the reproductively inactive adult is strongly lobulated, but the cavities and recesses largely disappear when the lumen expands during active secretion. The cells in the recesses appear to be the most active secretory units (Moore, Price \& Gallagher, 1930); ten such cells were measured from each individual to give an average height.

Ten cells from acini of the dorsolateral prostate gland and ten from the ventral prostate gland were also measured. 
Statistical analysis of the data

A principal components analysis was performed on the measurements of reproductive activity. This multivariate technique detects symmetrical patterns within a set of variables that might be overlooked or misinterpreted in a bivariate analysis, such as the calculation of correlation coefficients. In a principal components analysis, a matrix of correlation coefficients between each possible pair of variables is reduced to a smaller number of principal components, each of which is a unique linear combination of the original variables. The most important principal component is listed first; it contains the greatest proportion of the total variance, and subsequent principal components contain smaller proportions of the variance. Each of the variables is assigned a loading within each principal component according to the strength of its relationship in that particular linear combination with all the other variables. Consequently, those variables with high loadings may be assumed to be more closely related to one another. Therefore, the analysis provides a means of looking at a complete set of variables and extracting a smaller number which account for most of the larger set. A more rigorous description of the principal components analysis may be found in Morrison (1967).

\section{RESULTS}

The means and standard deviations of the reproductive parameters in all the adult male pocket gophers trapped during the study are shown in Table 1.

TABLE 1

MEANS AND STANDARD DEVIATIONS OF REPRODUCTIVE PARAMETERS

IN ADULT MALE POCKET GOPHERS

\begin{tabular}{|c|c|c|}
\hline Parameter & $\begin{array}{c}\text { No. of } \\
\text { animals }\end{array}$ & Mean $\pm S . D$. \\
\hline $\begin{array}{l}\text { Body length }(\mathrm{mm}) \\
\text { Body weight }(\mathrm{g}) \\
\text { Testis volume }\left(\mathrm{mm}^{3}\right) \\
\text { Testis tubule diameter }(\mu \mathrm{m}) \\
\text { Stage of spermatogenesis } \\
\text { Leydig cell diameter }(\mu \mathrm{m}) \\
\text { Nucleus-cell ratio of Leydig cell }(\%) \\
\text { Leydig cell tissue volume }\left(\mathrm{mm}^{3}\right) \\
\text { Leydig cell tissue }(\% \text { of testis volume }) \\
\text { Epididymal tubule diameter }(\mu \mathrm{m}) \\
\text { Epididymal cell height }(\mu \mathrm{m}) \\
\text { Epididymal cell-tubule ratio }(\%) \\
\text { Seminal vesicle diameter }(\mathrm{mm}) \\
\text { Seminal vesicle cell height }(\mu \mathrm{m}) \\
\text { Dorsolateral prostate cell height }(\mu \mathrm{m}) \\
\text { Ventral prostate cell height }(\mu \mathrm{m})\end{array}$ & $\begin{array}{l}61 \\
62 \\
59 \\
61 \\
61 \\
59 \\
59 \\
55 \\
55 \\
52 \\
52 \\
52 \\
52 \\
54 \\
51 \\
36\end{array}$ & $\begin{array}{c}178 \cdot 9 \pm 23 \cdot 6 \\
213 \cdot 5 \pm 48 \cdot 5 \\
3282 \cdot 8 \pm 1492 \cdot 6 \\
160 \cdot 4 \pm 41 \cdot 0 \\
9 \cdot 3 \pm 6 \cdot 6 \\
8 \cdot 2 \pm 1 \cdot 3 \\
67 \cdot 4 \pm 5 \cdot 9 \\
370 \cdot 2 \pm 271 \cdot 9 \\
11 \cdot 3 \pm 6 \cdot 3 \\
226 \cdot 3 \pm 85 \cdot 4 \\
22 \cdot 5 \pm 5 \cdot 8 \\
12 \cdot 5 \pm 6 \cdot 4 \\
1.9 \pm 1 \cdot 0 \\
17 \cdot 5 \pm 3 \cdot 8 \\
17 \cdot 4 \pm 3 \cdot 9 \\
14 \cdot 9 \pm 2 \cdot 2\end{array}$ \\
\hline
\end{tabular}

Three of the five most significant principal components are shown in Table 2.

Principal Component 1 was significant in these considerations because of the high loading given to body length. This parameter would clearly not have fluctuated from season to season and is considered to be a measure of age. The 
high loadings on those parameters whose values are starred in Table 2 under the heading of Principal Component 1 suggest that they would therefore change with age.

The comparative loadings in Principal Component 2 (which bears no relationship to age or to Principal Component 1) indicated that Leydig cell tissue

TABLE 2

THREE SIGNIFICANT PRINCIPAL COMPONENTS FROM ANALYSIS OF REPRODUCTIVE ORGANS OF MALE POCKET GOPHERS

\begin{tabular}{|c|c|c|c|}
\hline \multirow[b]{2}{*}{ Parameter } & \multicolumn{3}{|c|}{ Principal component } \\
\hline & 1 & 2 & 3 \\
\hline $\begin{array}{l}\text { Body length } \\
\text { Body weight } \\
\text { Testis volume } \\
\text { Testis tubule diameter } \\
\text { Stage of spermatogenesis } \\
\text { Leydig cell diameter } \\
\text { Nucleus-cell ratio of Leydig cell } \\
\text { Leydig cell tissue volume } \\
\text { Leydig cell tissue (\% of testis volume) } \\
\text { Epididymal tubule diameter } \\
\text { Epididymal cell height } \\
\text { Epididymal cell-tubule ratio } \\
\text { Seminal vesicle diameter } \\
\text { Seminal vesicle cell height } \\
\text { Dorsolateral prostate cell height } \\
\text { Ventral prostate cell height }\end{array}$ & $\begin{array}{c}0 \cdot 86^{*} \\
0 \cdot 14 \\
0 \cdot 54^{*} \\
0 \cdot 89^{*} \\
0.93^{*} \\
-0 \cdot 65^{*} \\
-0.72^{*} \\
0.33 \\
-0.12 \\
0.39 \\
-0.19 \\
0 \cdot 54^{*} \\
0 \cdot 03 \\
0 \cdot 18 \\
0.18 \\
0 \cdot 19\end{array}$ & $\begin{array}{r}0.07 \\
-0.04 \\
0.16 \\
-0.03 \\
-0.05 \\
0.19 \\
-0.42^{*} \\
0.83^{*} \\
0.94^{*} \\
-0.02 \\
-0.12 \\
0.12 \\
-0.21 \\
0.08 \\
0.06 \\
0.12\end{array}$ & $\begin{array}{c}-0.02 \\
0.19 \\
0.21 \\
0.29 \\
0.19 \\
0.71^{*} \\
-0.03 \\
0.17 \\
0.06 \\
0.41^{*} \\
0.13 \\
0.53^{*} \\
0.49^{*} \\
0.86^{*} \\
0.86^{*} \\
0.76^{*}\end{array}$ \\
\hline
\end{tabular}

* Indicates most important loadings.

volume and the percentage of Leydig cell tissue in the testis tend to be greater when the proportion of cytoplasm to nucleus in the Leydig cell is larger.

Accordingly, in Principal Component 3, both the Leydig cell diameter and the epithelial height in each of the accessory sex glands and in the epididymis increased concurrently.

\section{DISCUSSION}

The reproductive cycle of the south-eastern pocket gopher may be expected to deviate somewhat from a standard seasonal pattern, not only because of the animal's fossorial habit but also because of the lack of any significant environmental stress in the southern parts of its range. The deviation seems to be derived from the differential responses of the males to various environmental factors. Consequently, one might expect to find a variety of reproductive 'cycles' within a population at any given time, depending on the responses of each organism to his environment.

The principal components analysis was chosen to identify similar patterns of change among the male reproductive organs. It seemed likely that the lack of a clear-cut difference between individuals in active and inactive reproductive conditions would facilitate the detection of these patterns. Consequently, previously unsuspected relationships might be inferred. 
Principal Component 1 in the analysis contained the greatest proportion of the variance and, hence, may be considered the most informative. Accordingly, the high loading on spermatogenesis, associated with body length or age, indicates that it is not strictly a cyclic event, as might otherwise be suspected. Instead, the rate of sperm production appears to increase with age. Consequently, if reproductive activity varies throughout a yearly period in all males, the source of this variation must lie in another part of the reproductive system.

After puberty, the testis volume apparently also increases with age. This could be due to either, or both, of two factors: an increase in testis tubule size, or an increase in the volume of interstitial tissue. Testis tubule diameter was found to increase with age; the increase in volume of the total Leydig cell tissue proved not to be significant. The percentage of Leydig cell tissue volume to total volume decreased (but not significantly), and the diameter of the Leydig cell itself decreased with age. The diameter of the Leydig cell nucleus also decreased significantly with age relative to the diameter of the entire cell.

The diameter of the Leydig cell in immature males averaged $5.6 \mu \mathrm{m}$, the diameter of the nucleus averaging $84 \%$ of this $(n=11)$. The diameter of the nucleus in the mature male, however, comprised only $67 \%$. The growth of Leydig cells in the testis is probably initiated at puberty and is characterized by a disproportionate increase in the growth rate of the cytoplasm relative to the nucleus. An increase in number may also occur. The Leydig cell is, therefore, larger after than before puberty, but its diameter, according to the principal components analysis, subsequently decreases with age. Conaway (1959) recorded a similar phenomenon in the eastern mole, Scalopus aquaticus. The infantile testis was characterized by abundant but small Leydig cells with very little cytoplasm. Early increases in testis volume were due primarily to increases in Leydig cell volume until testis tubule enlargement and the concurrent beginning of spermatogenesis became significant at puberty. After this stage, the diameter of the Leydig cell decreased by one-third, increasing again slightly at the end of the active breeding period. The cell diameter was found to be largest during the period of sexual inactivity. Similar studies on the rat (Clegg, 1966), bull (Albert, 1961) and hippopotamus (Laws \& Clough, 1966) support the conclusion that an overall decrease in size of Leydig cells in pocket gophers as well as a decrease in percentage of total testis volume would not be an unusual situation. The relationships in Principal Component 2 between the measurements of the Leydig cell reinforce these observations.

Principal Component 3, however, shows that the Leydig cell diameter actually increases along with the epithelial cells in the accessory sex glands. Unlike the situation described earlier in moles (Conaway, 1959), hormone secretion is presumably associated here with an increase, necessarily temporary, in the diameter of the Leydig cell. This evidence, together with the lack of correlation between epithelial heights and age, suggests that an occasional, perhaps cyclic, increase and decrease of Leydig cell diameter may be imposed on the long-term pattern of diminution. It is likely that seasonal fluctuations in hormonal secretion by the Leydig cell affect the activity levels of the accessory sex glands. This would be reflected in the variations in breeding intensity which have been observed; a sperm storage mechanism may be operating to accommodate 
spermatozoa produced during periods of low intensity. Similarly, the increase in epididymal cell height associated with these changes corresponds to the observations summarized by Mann (1964), who suggested that survival of spermatozoa was strongly dependent on secretions from the epididymal epithelium that were, in turn, induced by androgen secretion.

\section{ACKNOWLEDGMENTS}

The research presented in this paper is part of a dissertation submitted to the University of Florida in partial fulfilment of the requirements for the degree of Doctor of Philosophy. I am indebted to Dr David W. Johnston, Dr John H. Kaufmann, Dr E. G. Franz Sauer and Dr Daniel B. Ward for their encouragement and helpful criticism during the course of this project. Dr John Thornby generously offered much advice and assistance with the statistical analysis of the data; Mr Leon Rosenson made several helpful criticisms of the manuscript; and $\mathrm{Mr}$ Thomas Krakauer assisted me several times in trapping. Permission to trap on Stengel Field was kindly granted by Mr A. Arano. The University of Florida Computing Center provided the facilities for the statistical analysis.

\section{REFERENCES}

Albert, A. (1961) The mammalian testis. In: Sex and Internal Secretions, 3rd edn, vol. 1, p. 305. Ed. W. C. Young. Williams \& Wilkins, Baltimore.

CLEGG, E. J. (1966) Pubertal growth in the Leydig cells and accessory reproductive organs of the rat. 7. Anat. 100, 369.

Conaway, C. H. (1959) The reproductive cycle of the eastern mole. F. Mammal. 40, 180.

Groome, J. R. (1940) The seasonal modification of the interstitial tissue of the testis in the fruit bat (Pteropus). Proc. zool. Soc. Lond. 110, 37.

Johnson, O. W. \& Buss, I. O. (1967) The testis of the African elephant (Loxodonta africana). I. Histological features. 7. Reprod. Fert. 13, 11.

LAws, R. M. \& Clovgh, G. (1966) Observations on reproduction in the hippopotamus Hippopotamus amphibius Linn. In: Comparative Biology of Reproduction in Mammals, p. 117. Ed. I. W. Rowlands. Academic Press, London.

MANN, T. (1964) The biochemistry of semen and of the male reproductive tract. 2nd edn. John Wiley, New York.

Moore, C. R., Price, D. \& Gallagher, T. F. (1930) Rat-prostate cytology as a testis hormone indicator and the prevention of castration changes by testis-extract injections. Am. F. Anat. 45, 71 .

Morrison, D. F. (1967) Multivariate statistical methods. McGraw-Hill, New York.

Roosen-Runge, E. G. \& Giesel, L. G., JR (1950) Quantitative studies on spermatogenesis in the albino rat. Am. F. Anat. 87, 1.

Spencer, R. P. (1968) Changes in testicular allometric growth curves. Yale F. Biol. Med. 40, 313.

WING, E. S. (1960) Reproduction in the pocket gopher in north-central Florida. F. Mammal. 41, 35. 